\title{
LITERAL BODIES (SOMATA): A TELESTICH IN OVID (METAMORPHOSES 1.406-11)*
}

\begin{abstract}
This article draws attention to the presence of a previously unnoticed transliterated telestich (SOMATA) in the transformation of stones into bodies in the episode of Deucalion and Pyrrha in Ovid's Metamorphoses (1.406-11). Detection of the Greek intext, which befits the episode's amplified bilingual atmosphere, is encouraged by a number of textual cues. The article also suggests a ludic connection to Aratus' Phaenomena.
\end{abstract}

Keywords: Ovid; Metamorphoses; wordplay; telestich; Aratus

Jupiter's devastating flood at the beginning of the Metamorphoses exposes an apocalyptic landscape with little hope for restoration (Met. 1.348-9). Deucalion and Pyrrha turn to the gods and are ordered to repopulate the Earth by casting the stones (saxa) of the 'Great Mother' behind them (1.381-3), saxa that will eventually become bodies containing flesh, bones and veins (1.407-10).

Ovid's teasing with language in this passage is pervasive. First, the switch from the literal to the figurative meaning of magna parens and of lapides (1.393-4) allows the couple to interpret correctly the oracle (1.399). ${ }^{1}$ Second, the episode's last two lines disclose an aetiological allusion to the Greek etymology behind $\lambda \alpha$ ó $\varsigma$ 'people' and $\lambda \hat{\alpha} \alpha \varsigma$ 'stones' (1.414-15 inde genus durum sumus experiensque laborum, | et documenta damus qua simus origine nati 'from there we are a hard race, accustomed to difficulties, and we give proof of the origin from which we are born'). ${ }^{2}$

Remaining attuned to wordplay, I seek to highlight the presence of an intext in the lines that describe the metamorphosis of stones into bodies, a transliterated telestich that spells SOMATA $(\sigma \dot{\omega} \mu \alpha \tau \alpha)$, which complements, on the margins, this transformation. ${ }^{3}$ Here is the typographically enhanced text (Met. 1.403-13):

* I would like to thank Alison Sharrock for her vital encouragement and advice: Ovid truly never ceases to amaze. I would also like to express my gratitude to the anonymous reader and to Bruce Gibson for their helpful suggestions.

${ }^{1}$ For a novel re-reading of the episode, see A. Feldherr, 'Between a rock and a hard race: gender and text in Ovid's Deucalion and Pyrrha episode (Met. 1.313-415)', in A.R. Sharrock, D. Möller and M. Malm (edd.), Metamorphic Readings: Transformation, Language, and Gender in the Interpretation of Ovid's Metamorphoses (Oxford, 2020), 54-83.

2 Already at play in the Latin sources in Lucretius (5.925-6) and Virgil (G. 1.61-3, 2.340-2). See A. Barchiesi, Ovidio, Metamorfosi. Volume I: Libri I-II (Milan, 2005), 199-200 and J.J. O'Hara, True Names: Vergil and the Alexandrian Tradition of Etymological Wordplay. New and Expanded Edition (Ann Arbor, 2017), 255.

${ }^{3}$ For Ovidian telestichs, see K. Mitchell, 'Acrostics and telestichs in Augustan poetry: Ovid's edgy and subversive sideswipes', CCJ 66 (2020), 165-81. Mitchell identifies the intext SOMA at Met. 15.408-11 in the description of the hyena's bodily metamorphosis from female to male, which creates a striking ring-composition of wordplay when taken in conjunction with the telestich I propose here (cf. also the SOMA at Ov. Pont. 1.10.38-42). See also M. Hanses, 'Naso Deus: Ovid's hidden signature in the Metamorphoses', in A.R. Sharrock, D. Möller and M. Malm (edd.), Metamorphic 
mox ubi creuerunt naturaque mitior illis contigit, ut quaedam, sic non manifesta, uideri

forma potest hominis, sed uti de marmore coepta, non exacta satis rudibusque simillima signiS.

quae tamen ex illis aliquo pars umida sucO et terrena fuit, uersa est in corporis usuM; quod solidum est flectique nequit, mutatur in oss A; quae modo uena fuit, sub eodem nomine mansiT; inque breui spatio superorum numine saxA missa uiri manibus faciem traxere uirorum et de femineo reparata est femina iactu. ${ }^{4}$

Soon, when [the stones] grew and a milder nature took hold of them, the shape of a human can be perceived, a sort of shape, thus not evident, but as if begun from marble, not yet sufficiently finalized and most similar to unwrought sculptures. Nevertheless, the earthly part of the stones that had been moistened by some liquid was transformed into the function of flesh; what is solid and unable to be bent is changed into bones; and what had been just now a vein has remained under the same name; in a short space, through the divine power of the gods above, the stones cast from the hands of the man drew the appearance of men, and woman was re-formed from the woman's toss. ${ }^{5}$

The bilingual play between $\sigma \omega \dot{\mu} \alpha \tau \alpha$ and corporis (uersa est in corporis usum) identifies a clear 'verbal referent' in the Latin, a term coined by Morgan in the analysis of Aratus' LEPTE acrostic (Phaen. 783-7) to designate an acrostic when echoed in the lines and the theme of a given passage. ${ }^{6}$ These referents usually confirm 'that the intext's placement is deliberate'. ${ }^{7}$ SOMATA directly responds to the metamorphosis, as the transliterated Greek word for 'bodies' precisely corresponds to the subject matter. Each letter of the telestich, as rocks gradually cast by Ovid repeating the couple's actions, takes on the shape (forma) of the word $\sigma \dot{\omega} \mu \alpha \tau \alpha$, which aptly parallels the metamorphosis' telos. SOMATA also exceeds Morgan's quantitative rule ('any gamma-acrostic of five or more letters is deliberate'). ${ }^{8}$

Readings: Transformation, Language, and Gender in the Interpretation of Ovid's Metamorphoses (Oxford, 2020), 126-41. For Horatian telestichs, see E. Fredericksen, 'When enough is enough: an unnoticed telestich in Horace (Satires 1.4.14-18)', CQ 68 (2018), 716-20. For the status of Virgilian wordplay, see J.T. Katz, 'The Muse at play: an introduction', in J. Kwapisz, D. Petrain and M. Szymánski (edd.), The Muse at Play: Riddles and Wordplay in Greek and Latin Poetry (Berlin, 2013), 1-30 and id., 'Another Vergilian signature in the Georgics?', in P. Mitsis and I. Ziogas (edd.), Wordplay and Powerplay in Latin Poetry (Berlin, 2016), 69-85. For persuasive Horatian acrostics, see T. Kearey, 'Two acrostics in Horace's Satires (1.9.24-8, 2.1.7-10)', CQ 69 (2019), 734-44. The recent contributions by M.J. Robinson, 'Looking edgeways: pursuing acrostics in Ovid and Vergil', CQ 69 (2019a), 290-308 and id., 'Arms and a mouse: approaching acrostics in Ovid and Vergil', $M D 82$ (2019b), 23-73 offer splendid assessments of ancient and contemporary discourses on acrostics, advancing valuable re-evaluations of the broader significance of Augustan wordplay. SOMATA has not been, to my knowledge, detected: telestichs are not included in the original list of Zufallsakrosticha in I. Hilberg, 'Ist die Ilias Latina von einem Italicus verfasst oder einem Italicus gewidmet?', WS 21 (1899), 264-305.

${ }^{4}$ The text of the Metamorphoses used is that of R.J. Tarrant, P. Ovidi Nasonis Metamorphoses (Oxford, 2004). There are no textual problems that might affect interpretation.

5 Translations are my own.

${ }^{6}$ G. Morgan, 'Nullam, Vare ... chance or choice in Odes 1.18?', Philologus 137 (1993), 142-5, at 143, who explores Fowler's analysis of the MARS/MARTEM acrostic at Aen. 7.601-4, first noticed by Hilberg (n. 3), 267; cf. D.P. Fowler, 'An acrostic in Vergil (Aeneid 7.601-4)', CQ 33 (1983), 298.

${ }^{7}$ Morgan (n. 6), 143; quotation from Hanses (n. 3), 128. For issues of deliberate vs accidental acrostics (which echo gargantuan intertextual disputes), see Robinson (n. 3 [2019b]). I defer to Lyne's pragmatic approach, espoused by Robinson, to 'judge each case on its merits'.

${ }^{8}$ Morgan (n. 6), 145. 
There are a number of self-conscious clues in the text that announce the telestich to the readers. First, verbal patterns of repetition imitate the story's own development: the word-variations in the programmatic line preceding our passage (1.402 mollirique mora mollitaque ducere formam 'and [the stones began] to soften progressively and, once soft, to bring forward a shape') 'convey the passing from one stage in the process [of metamorphosis] to another'. ${ }^{9}$ Likewise, the recurrence of the $s$ sound in the line that begins the telestich (non exacta satis rudibusque simillima signis) alerts the reader to its commencement.

The use of signa equally forewarns us to be on the lookout for textual signs. ${ }^{10}$ signum starkly calls to mind the crucial Aratean word $\sigma \hat{\eta} \mu \alpha$ ('sign', pl. $\sigma \dot{\eta} \mu \alpha \tau \alpha$ ), a marker not only of wordplay ahead of the LEPTE acrostic itself (twice repeated at Phaen. 772, 777) but also a key signifier of the written word in the cosmos of the Phaenomena. ${ }^{11}$ The sky, with its constellations skilfully arranged by Zeus, exists to

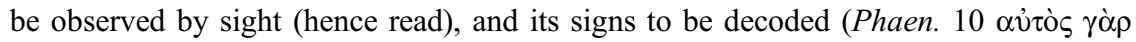

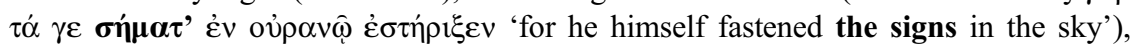
as the god opens up the firmament for interpretation just before the acrostic too (Phaen. 768-72). ${ }^{12}$ Ovid alludes to Aratus at the beginning of the Fasti, where he will sing of signa 'constellations', ${ }^{13}$ risen (orta) and now visible, thus evoking Aratus' title, the Phaenomena. ${ }^{14}$ The poet's name might even be lurking in anagrammatic form in the same lines (Fast. 1.2 lapsaque sub terras ortaque signa canam, where terr/as orta $>$ rearranged, becomes Aratos). ${ }^{15}$ The usage of signa to activate

${ }^{9}$ L. Barkan, The Gods Made Flesh: Metamorphosis and the Pursuit of Paganism (New Haven, 1986), 32, with Feldherr (n. 1), 75-6. forma is a key Ovidian word (Met. 1.1-2 in noua fert animus mutatas dicere formas $\mid$ corpora) with manifold meanings: see L. Enterline, The Rhetoric of the Body from Ovid to Shakespeare (Cambridge, 2000), 6-7, 31-2, 64. The M of the SOMA telestich that Mitchell (n. 3) identifies in Book 15 is likewise announced: passa marem est, nunc esse marem miremur hyaenam (Met. 15.410).

${ }^{10}$ A literal certum signum, to paraphrase D. Feeney and D.P. Nelis, 'Two Virgilian acrostics: certissima signa?', CQ 55 (2005), 644-6. The use of signa at G. 1.438-9 (and the metathesis at 1.427-8) sets in motion Virgil's response to Aratus with the seemingly hidden signature of MA-VE-PV, on which see M. Haslam, 'Hidden signs: Aratus Diosemeiai 46ff., Vergil Georgics 1.424ff.', HSPh 94 (1992), 199-204 and Robinson (n. 3 [2019a]), 294 n. 18 and 297-8 n. 48.

11 J. Danielewicz, 'Vergil's certissima signa reinterpreted: the Aratean LEPTE-acrostic in Georgics 1', Eos 100 (2013), 287-95, at 290-1 again sees in Manilius' use of signa a direct allusion to Aratus. $\sigma \hat{\eta} \mu \alpha$ occurs forty-seven times and becomes an essential idiom of Aratean semantics: see K. Volk, 'Aratus', in J.J. Clauss and M. Cuypers (edd.), A Companion to Hellenistic Literature (Malden, Mass., 2010), 197-210, at 200-4, expanded in K. Volk, 'Letters in the sky: reading the signs in Aratus' Phaenomena', AJPh 133 (2012), 209-40, at 215-16 and 218-19. For scholarship on LEPTE, first appraised by J.-M. Jacques, 'Sur un acrostiche d'Aratos (Phén., 738-787)', REA 62 (1960), 48-61, see Volk (this note [2012]), 226-32 and M. Hanses, 'The pun and the moon in the sky: Aratus' $\Lambda$ ЕПТН acrostic', $C Q 64$ (2014), 609-14, at 609-10 n. 2, well complemented by J. Danielewicz, 'One sign after another: the fifth $\Lambda$ ЕПТН in Aratus' Phaen. 783-4?', CQ 65 (2015), 387-90 and S.M. Trzaskoma, 'Further possibilities regarding the acrostic at Aratus 783-7', CQ 66 (2016), 785-90.

${ }_{12}$ See Volk (n. 11 [2012]), 214-15 for the Near Eastern concept of stars as 'written' in the sky and 215-23 for Aratean $\sigma \eta \dot{\mu} \mu \tau \alpha$ and epigraphic practices. In both Aratus and Ovid, prior to the wordplay, Zeus/Jupiter looms large, and mortals are afraid as they face water-related disasters (the sailor at sea fears a sudden storm at Phaen. 765-8; Deucalion and Pyrrha are surrounded by flooded land at Met. 1.313-19, and are afraid of drowning at Met. 1.353-62).

${ }_{13}$ As in Lucr. 1.2: caeli ... labentia signa ('the sky's gliding signs').

14 A. Barchiesi, The Poet and the Prince. Ovid and the Augustan Discourse (Berkeley, 1997), 51 n. 7. On Ovid and Aratus in the Fasti, see E. Gee, Ovid, Aratus and Augustus. Astronomy in Ovid's Fasti (Cambridge, 2000), 66 on this line.

15 As argued by D.P. Nelis, 'Arise, Aratus', Philologus 160 (2016), 177-9. 
(Aratean) wordplay does not therefore seem arbitrary. The arresting resemblance (simillima) of $\sigma \dot{\omega} \mu \alpha \tau \alpha$ and $\sigma \dot{\eta} \mu \alpha \tau \alpha$ might even intimate a further play on Ovid's part: the poet literally lowers Aratus' buzzword designated for celestial signs by adapting an orthographic neighbour in a substantially more earth-bound context.

In light of the telestich, Ovid's heightened irony in this passage then assumes a self-referential tone and becomes a telltale sign that something more humorous is at play. His parenthetical remark (1.400 saxa (quis hoc credat nisi sit pro teste uetustas?) 'the stones (who would believe this, if it were not for antiquity as a witness?)') resonates as a candid challenge to readers to fine-tune their perceptiveness: once detected, in fact, the telestich dispels any doubt on the real nature of these rocks. ${ }^{16}$ Fittingly, the narratorial interjection isolates the true subject of the passage, the saxa, thus setting these extraordinary rocks apart once again. ${ }^{17}$

The amplified emphasis on visuality and enargeia (1.404-5 sic non manifesta, uideri $\mid$ forma potest hominis) signals the onset of the telestich, and openly encourages readers to sharpen their visions and to scan the text vigilantly. ${ }^{18}$ Once the metamorphosis commences, each part of the human body begins to emerge: similarly, as the reader unfurls the physical scroll, each letter progressively materializes. ${ }^{19}$ The neuter gender of the word $\sigma \omega \mu \alpha \tau \alpha$ seems appropriately meaningful too: it is only when the telestich ends that a well-defined gender differentiation comes into view (1.412-13). Finally, the wordplay's completion is also suggestively made manifest. In a breue spatium, a temporal pointer and a spatial marker, the poet brings to a close both his metamorphosis and the telestich (inque breui spatio superorum numine saxa). ${ }^{20}$

The intext SOMATA thus runs parallel to every stage of the 'anthropogonic creativity' of the saxa-turned-corpora metamorphosis. ${ }^{21}$ Though not common, bilingual wordplay and transliterated Greek acrostics in Latin texts are generally recognized. ${ }^{22}$ The Ovidian episode, concluding with a non-translated Greek aetiology, is already

16 On Ovid's wit in another narrative intrusion (Met. 1.397 sed quid temptare nocebit? 'what harm will it do to try?'), see G. Tissol, The Face of Nature: Wit, Narrative, and Cosmic Origins in Ovid's Metamorphoses (Princeton, 1997), 128-9. For acrostics as testaments to the erudition of poets (and Cicero), see now E.P. Rick, 'Cicero belts Aratus: the bilingual acrostic at Aratea 317-20', CQ 69 (2019), 222-8.

${ }_{17}$ Feldherr (n. 1), 72: 'the saxa, so to speak, [are] hanging in the air'.

18 See Feldherr (n. 1), 75, and 72-7 for an analysis of Ovidian concerns of representation vs reality.

19 See Feldherr (n. 1), 66-7 for the reification of language via metaphors here. See, among others, J.D. Hejduk, 'Was Vergil reading the Bible? Original sin and an astonishing acrostic in the Orpheus and Eurydice', Vergilius 64 (2018), 71-102, at 73-4 and Hanses (n. 3), 126-7 for the suitability of acrostics and ancient reading habits.

${ }^{20}$ The final letter of SOMATA derives from saxa, an appropriate ring-composition ending.

${ }^{21}$ Quoting C. Segal, 'Ovid's metamorphic bodies: art, gender, and violence in the Metamorphoses', Arion 5.3 (1998), 9-41, at 17.

${ }^{22}$ In addition to $S O M A$, Mitchell (n. 3) identifies the following transliterated telestichs in Ovid: ASTER (Pont. 3.1.130-4), ANER (Fast. 2.15-18), SOROS (Tr. 3.3.79-83; Fast. 1.17-21), CANON (Fast. 1.299-303). For transliterated Greek wordplay, see Rick (n. 16); Danielewicz (n. 11 [2013]), 290 and id., 'ASTER, ASTER, ASTER: a triple transliterated Greek acrostic in Vergil's Eclogue 4.361-6', Philologus 163 (2019), 361-6. L.J. Kronenberg, 'The tenth of age of Apollo and a new acrostic in Eclogue 4', Philologus 161 (2017), 337-9 identifies the syllabic acrostic DE-CA-TE (Ecl. 4.9-11) as a reference to the Etruscan doctrine of the ten saecula. For bilingual wordplay in Augustan poets, see P. Roche, 'Citing Empedocles: a bilingual pun at Ovid, Met. 15.58', CQ 68 (2018), 552-6 and C. Nappa, 'Cold-blooded Virgil: bilingual wordplay at Georgics 2.483-9', CQ 52 (2002), 617-20. On bilingualism, see J.T. Katz, "Vergil translates Aratus: Phaenomena 1-2 and Georgics 1.1-2', MD 60 (2008), 105-23, at 105 n. 2. 
steering the reader towards an intensified bilingual/bi-literal atmosphere. The telestich SOMATA fits this context well. ${ }^{23}$

I conclude, in pleasant and open conversation with Fowler's legendary men, by offering a final reflection in the hope of fostering further theories with regard to this telestich and its place, perhaps vis-à-vis Ovidian poetics and Augustan wordplay more generally. ${ }^{24}$ It seems to me that the verb uerto in the line at the heart of the telestich (et terrena fuit, uersa est in corporis usum) ought to be significant, as it draws attention to the bicultural play at work. ${ }^{25}$ Aratus, as some of his Hellenistic readers already perceived, included his name in the second line of the Phaenomena (1-2 $\dot{\varepsilon} \hat{\omega} \mu \varepsilon v \mid \grave{\boldsymbol{\alpha}} \rho \rho \eta \tau o v)$. Virgil too spotted it and alluded to it via the periphrastic terram | uertere 'to turn the earth' (G. 1.1-2, where terra is arret backwards) in place of the more common arare/aratus. ${ }^{26}$ If we accept that Virgil's use of uerto is 'explicitly

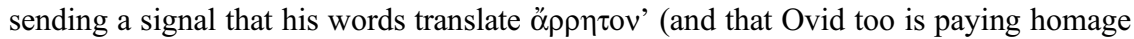
to Aratus in the Fasti), uerto in our passage may then be interpreted at once as a command to translate corporis in order to track down $\sigma \omega \dot{\mu} \alpha \tau \alpha$ and as another Ovidian gesture towards the master of wordplay (thus corroborating Virgil's own previous jeu de mots). ${ }^{27}$ In these 'agricultural' verbal games, Aratus stands as the arator who has prepared the fertile terrain, whilst Ovid, in this new beginning, positions himself as his natural successor, the one who seeds this tilled land of wordplay. Deucalion and Pyrrha are, after all, sowing 'every kind of seed', ${ }^{28}$ even rocky ones belonging to Mother Earth: ${ }^{29}$ stones that, once terrestrial (et terrena fuit), wondrously turn (uersa est) into the first human bodies.

University of Manchester

JULENE ABAD DEL VECCHIO julene.abaddelvecchio@manchester.ac.uk

${ }^{23}$ Linguistic mutability, an Ovidian staple, is also felt in the polyvalent uena (sub eodem nomine mansit); cf. liber ('book'/'tree-bark') in Daphne's story (Met. 1.549), with J. Farrell, 'The Ovidian corpus: poetic body and poetic text', in P. Hardie, A. Barchiesi and S.E. Hinds (edd.), Ovidian Transformations: Essays on Ovid's Metamorphoses and its Reception (Cambridge, 1999), 127-41. Cicero code-switches to $\sigma \hat{\omega} \mu \alpha$ when referring to a 'body' of work (Cic. Att. 2.1.3 hoc totum $\sigma \hat{\omega} \mu \alpha$ curabo ut habeas).

24 Fowler (n. 6).

${ }^{25}$ Widely applied to the adaptation of Greek into a new Latin form; cf. Livius Andronicus' uirum ... uersutum, that is, Ulysses, with S.E. Hinds, Allusion and Intertext: Dynamics of Appropriation in Roman Poetry (Cambridge, 1998), 58-62. On uerto and translation, see Plaut. Trin. 19, Cic. Fin. 1.3.7 and Livy 25.39.12, with A. Traina, Vortit barbare: le traduzioni poetiche da Livio Andronico a Cicerone (Rome, 1970), 55-65.

${ }^{26}$ See Katz (n. 22), 109-10 for full references and 111-17 for an analysis of Virgil's verbal strategies, and C. Castelletti, 'Following Aratus' plow: Vergil's signature in the Aeneid', MH 69 (2012), 83-95.

27 These $\sigma \dot{\mu} \mu \alpha \tau \alpha$ (and the telestich by proxy) can be seen as part of the promised noua corpora at Met. 1.1-2.

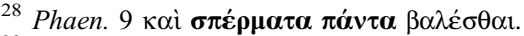

29 Variations of terra appear ten times in the episode alone (twice at 1.314, twice at 1.329, 1.349, $1.354,1.364$, twice at $1.393,1.408)$. For the agricultural imagery in the myth of Deucalion and Pyrrha, see M. Paschalis, 'Semina ignis: the interplay of science and myth in the song of Silenus', AJPh 122 (2001), 201-22, at 205-10. 